\title{
ANALISIS IMPLEMENTASI CUSTOMER RELATIONSHIP MANAGEMENT DAN MARKETING PUBLIC RELATIONS TERHADAP NILAI PELANGGAN DAN DAMPAKNYA TERHADAP LOYALITAS PELANGGAN: STUDI KASUS GRAND TROPIC SUITES' HOTEL
}

\author{
Natalia; Cooky Tri Adhikara; Shirley Agusthina \\ Jurusan Manajemen, Fakultas Ekonomi dan Komunikasi, BINUS University \\ Jln. K.H. Syahdan No. 9, Palmerah, Jakarta Barat 11480
}

\begin{abstract}
The impact of the globalization resulted in the business world being colored by the increase of high competition. Because of that the perpetrators of the business must continue to maintain the continuity of his business and to try to look for the opportunity by making use of the superiority that was owned. One of the methods that could be followed was constructive the customer's loyalty by maintaining the available customer so as they were loyal and did not move to the other competitor. Therefore, it is important for the company to create the value of the superior for the customers. The case study was about Customer Relationship Management program (CRM) and Marketing Public Relations (MPR) that was carried out by Grand Tropic Suites' Hotel to create the value of the superior of the customers where being expected with this superior value to be able to affect the customer to loyal to the Hotel. The aim of this research was to analyze the implementation of Customer Relationship Management programs (CRM) and Marketing Public Relations (MPR) towards the Perceived Value and it impact towards Customer Loyalty.
\end{abstract}

Keywords: Customer Relationship Management (CRM), Marketing Public Relations MPR), perceived value, customer loyalty

\begin{abstract}
ABSTRAK
Dampak dari globalisasi mengakibatkan dunia bisnis akan diwarnai oleh persaingan yang semakin tinggi. Oleh karena itu pelaku bisnis harus tetap mempertahankan kontinuitas bisnisnya dan berusaha mencari peluang dengan memanfaatkan keunggulan yang dimiliki. Salah satu cara yang dapat ditempuh ialah membangun loyalitas pelanggan dengan mempertahankan pelanggan yang ada sehingga mereka loyal dan tidak pindah ke pesaing lain. Oleh karena itu, penting bagi perusahaan untuk menciptakan nilai superior bagi para pelanggan. Studi kasus adalah program Customer Relationship Managtement(CRM) dan Marketing Public Relations (MPR) yang dilakukan oleh Grand Tropic Suites' Hotel untuk menciptakan nilai superior para pelanggan dimana diharapkan dengan nilai yang superior tersebut dapat mempengaruhi pelanggan untuk loyal kepada Hotel. Tujuan penelitian ini adalah menganalisa implementasi dari program-program Customer Relationship Management(CRM) dan Marketing Public Relations (MPR) terhadap Nilai Pelanggan dan Dampaknya terhadap Loyalitas Pelanggan.
\end{abstract}

Kata kunci: Customer Relationship Management (CRM), Marketing Public Relations (MPR), nilai pelanggan, loyalitas pelanggan 


\section{PENDAHULUAN}

Dalam era globalisasi, tingkat ketergantungan antar bangsa tidak dapat dihindari. Perkembangan ilmu pengetahuan, teknologi dan informasi mendorong terjadinya perdagangan bebas dimana dunia seakan-akan tanpa batas. Hal ini akan menimbulkan sebuah paradigma borderless world, yaitu dunia yang tidak mengenal batas-batas territorial kedaulatan bangsa dan negara. Sektor usaha yang dirasakan semakin berkembang akibat dari adanya globalisasi adalah sektor jasa. Hal ini antara lain ditandai adanya perubahan dalam kontribusi sektoral terhadap output nasional sebagai akibat terjadinya pergeseran tenaga kerja nasional dari sektor pertanian ke sektor industri untuk kemudian menuju ke sektor jasa.

Menurut data yang didapat dari Biro Pusat Statistik, Industri Hotel sendiri mengalami peningkatan yang cukup tinggi di sekitar tahun 2002. Namun terjadi penurunan yang cukup drastis di industri Hotel dikarenakan adanya berbagai macam masalah, misalnya kasus terjadinya pemboman di berbagai belahan di Indonesia (terutama Jakarta dan Bali). Oleh karena itu pelaku bisnis harus tetap mempertahankan kontinuitas bisnisnya dan berusaha mencari peluang dengan memanfaatkan keunggulan yang dimiliki. Salah satu cara yang dapat ditempuh ialah membangun loyalitas pelanggan dengan mempertahankan pelanggan yang ada sehingga mereka loyal dan tidak pindah ke pesaing lain. Oleh karena itu, penting bagi perusahaan untuk menciptakan nilai superior bagi para pelanggan. Salah satu cara menciptakan nilai pelanggan tersebut yaitu dengan menerapkan program Customer Relationship Management, suatu strategi untuk memanjakan pelanggan agar tidak berpaling ke pesaing. Kemudian cara yang lain yaitu dengan memberikan informasi yang cukup mengenai perusahaan untuk menciptakan citra yang baik mengenai perusahaan. Selanjutnya pelanggan hotel akan melakukan Word of Mouth yang positif kepada orang lain.

Studi kasus adalah program Customer Relationship Managemen) dan Marketing Public Relations yang dilakukan oleh Grand Tropic Suites' Hotel untuk menciptakan nilai superior para pelanggan dimana diharapkan dengan nilai yang superior tersebut dapat mempengaruhi pelanggan untuk loyal kepada Hotel. Oleh karena pentingnya Customer Relationship Management dan Marketing Public Relations dalam industri perhotelan untuk membangun nilai pelanggan yang berdampak terhadap Loyalitas Pelanggan, maka dalam penelitian ini akan dibahas mengenai. Identifikasi masalah pada riset ini adalah untuk menjawab permasalahan-permasalahan yaitu, seberapa besar kontribusi Customer Relationship Management dan Marketing Public Relations secara simultan terhadap Nilai Pelanggan, dan seberapa besar kontribusi Customer Relationship Management, Marketing Public Relations dan Nilai Pelanggan secara simultan terhadap Loyalitas Pelanggan.

\section{Telaah Pustaka}

Customer Relationship Management (CRM) merupakan singkatan dari Customer Relationship Management, yaitu suatu strategi yang terpadu dan proses mendapatkan, mepertahankan dan berteman dengan pelanggan. Terdapat tiga tipe program CRM, yaitu Continuity Marketing, one-to-one marketing, dan partnering pogram (Seth, Parvatiyar \& Shainesh, 2000).

Marketing Public Relations (MPR) merupakan singkatan dari Marketing Public Relations, yaitu public relations yang dirancang untuk mendukung tujuan pemasaran (Kotler, Bowens, Makens; 2003:593). $M P R$ dapat berkontribusi terhadap berbagai tujuan pemasaran yaitu meningkatkan kesadaran, membangun kredibilitas, menstimulasi tenaga penjual dan saluran perantara, serta mengurangi biaya promosi. Marketing Public Relations yang efektif merupakan hasil dari suatu proses yang harus diintegrasikan dengan strategi permasaran perusahaan. Proses MPR terdiri dari beberapa langkah yaitu penelitian, membentuk tujuan pemasaran, menetapkan audiens sasaran, memilih pesan dan alat public relations, mengimplementasikan rencana public relations, serta mengevaluasi hasil 
(Kotler, Bowens \& Makens, 2003). Terdapat beberapa komponen dalam Hubungan Masyarakat dalam Pemasaran (Marketing Public Relations) yang menurut Kotler, Bowens, Makens (2003:604) adalah publikasi, events, berita, kegiatan sosial, serta media identitas.

Nilai Pelanggan/PERVAL (perceived value scale) merupakan suatu pengukuran dari nilai yang diterima yang diaplikasikan untuk mengukur produk tangible. Wahyuningsih (2004) mengembangkan suatu model mengenai komponen dari nilai pelanggan yang terdiri dari manfaat dan korbanan. Pembentukan loyalitas dapat dilakukan dengan penciptaan nilai yang diterima pelanggan merupakan selisih antara evaluasi calon pelanggan atas semua manfaat serta semua biaya tawaran tertentu dan alternatif-alternatif lain yang dipikirkan (Kotler; 2007). Dapat dilihat dalam persamaan berikut ini:

$$
\text { Value }(V)=\frac{\text { Beneft }(B)}{\operatorname{Cost}(C)}
$$

Keterangan:

$\mathrm{V}=$ Nilai

$\mathrm{B}=$ Manfaat yang dirasakan (Produk, Pelayanan, Karyawan dan Citra Perusahaan)

$\mathrm{C}=$ Korbanan (Korbanan moneter, Waktu, Energi, dan Psikologi)

Total nilai pelanggan adalah seperangkat manfaat yang diterima pelanggan dari produk atau jasa tertentu yang dikonsumsinya. Total korbanan pelanggan adalah seperangkat biaya pelanggan yang dikorbankan dalam mengevaluasi, mendapatkan, mempergunakan dan membuang suatu produk atau jasa tertentu. Adapun manfaat yang dirasakan pelanggan terdiri dari manfaat produk, pelayanan, karyawan, serta citra. Sedangkan korbanan oleh pelanggan adalaj korbanan moneter dan non-moneter yaitu waktu, energi, serta psikologis.

Loyalitas pelanggan adalah komitmen untuk bertahan secara mendalam untuk melakukan pembelian ulang atau berlangganan kembali produk atau jasa terpilih secara konsisten di masa yang akan datang, meskipun pengaruh situasi dan usaha-usaha pemasaran mempunyai potensi untuk menyebabkan perubahan perilaku. Konsep lain mengenai loyalitas pelanggan menyebutkan bahwa konsep loyalitas lebih mengarah kepada perilaku (behavior) dibandingkan dengan sikap (attitude) dan seorang pelanggan yang loyal akan memperlihatkan perilaku pembelian yang dapat diartikan sebagai pola pembelian yang teratur dan dalam waktu yang lama, yang dilakukan oleh unit-unit pembuat atau pengambil keputusan (Griffin, 2002). Pelanggan menjadi setia biasanya bukan disebabkan salah satu aspek dalam perusahaan saja, tetapi biasanya pelanggan menjadi setia karena paket yang ditawarkan seperti produk, pelayanan, dan harga. Kriteria untuk mengidentifikasi pelanggan setia, yaitu: (1) keinginan untuk membeli produk atau jasa dari perusahaan dan memberi perhatian yang lebih sedikit kepada produk atau jasa yang ditawarkan oleh pesaing; (2) merekomendasikan perusahaan, produk, pelayanan perusahaan dari mulut ke mulut kepada orang lain; (3) membeli lebih banyak ketika perusahaan memperkenalkan produk baru dan memperbaharui produk-produk yang ada; (4) membicarakan hal-hal yang baik tentang perusahaan dan produk-produknya; dan (5) kurang peka terhadap harga dan tindakan proaktif untuk memberikan saran produk atau jasa kepada perusahaan.

\section{METODE}

Penelitian ini merupakan jenis penelitian asosiatif dimana bertujuan untuk mengetahui hubungan antara 2 variabel atau lebih. Unit analisis yang diteliti yaitu individu (Guest Grand Tropic Suites' Hotel). Time Horizon yang digunakan yaitu One-Shoot Cross Section dimana informasi yang dikumpulkan hanya pada saat tertentu saja. 
Skala variabel yang digunakan adalah skala interval yaitu, skala yang memiliki jarak numerik pada skala mewakili jarak yang sama pada karakter yang diukur. Terdapat interval yang konstan/sama antara nilai skala. Data diperoleh dari penilaian Guest Hotel terhadap program-program CRM dan MPR dengan mengisi kuesioner yang telah disediakan dengan menggunakan skala likert yang berguna untuk mengetahui derajat ketidaksetujuan dan kesetujuan pelanggan terhadap pertanyaan yang ada pada kuesioner.

Untuk mendapatkan data yang akan diolah, maka teknik pengumpulan data yang dilakukan penulis dalam penelitian ini adalah: (1) penelitian lapangan/riset lapangan (field research) yaitu observasi, tinjauan langsung ke lapangan untuk membantu pengidentifikasian perilaku konsumen, dan kuesioner, menggunakan format pertanyaan yang menggunakan skala; (2) studi kepustakaan/riset kepustakaan (library research) yaitu studi yang dilakukan dengan cara mempelajari buku- buku wajib (textbooks), buku-buku pelengkap atau referensi, majalah, jurnal, laporan resmi dari perusahaan dan catatan kuliah yang relevan dengan permasalahan yang diteliti. Dengan studi kepustakaan ini dimaksudkan untuk memperoleh data sekunder dan landasan teori sebagai bahan untuk studi perbandingan.

Teknik pengambilan sampel dalam penelitian ini dimaksudkan untuk menduga/ mewakili nilai suatu populasi. Populasi dalam penelitian ini adalah customer yang mengunakan jasa Grand Tropic Suites' Hotel. Teknik Pengambilan sampel menggunakan rumus dari Taro Yamane, yaitu:

$$
n=\frac{N}{N \cdot d^{2}+1}
$$

Di mana:

$\mathrm{n}=$ Jumlah sampel

$\mathrm{N}=$ Jumlah populasi

$d^{2}=$ Presisi (ditetapkan 10\% dengan tingkat kepercayaan 95\%)

Berdasarkan data yang berhasil dikumpulkan diketahui Jumlah populasi pengunjung Grand Tropic Suites' Hotel dari bulan Januari 2008-September 2008 rata-ratanya adalah 3904 kamar yang terjual selama kurun waktu bulan Januari 2008-September 2008. Sehingga dengan menggunakan rumus yang ada jumlah sampel minimal untuk penelitian ini adalah:

$$
n=\frac{3904}{3904,0,1^{2}+1}
$$

$\mathrm{n}=97.5 \approx 100$ orang

Analisis jalur yang dikenal dengan path analysis dikembangkan pertama tahun 1920-an oleh seorang ahli genetika yaitu Sewall Wright (Joreskog \& Sorbom, 1996; Johnson \& Wichern, 1992). Path Analysis diartikan oleh Bhornstedt (1974 dalam Kusnendi, 2005), yang dikutip oleh Riduwan dan Engkos Ahmad Kuncoro (2007) bahwa "a technique for estimating the effect's a set of independent variables han on a dependent caribale from a set of observed correlations, given a set of hypothesized causal asymmetric relation among the varibales." Sedangkan Tujuan utama path analysis adalah ..... "a method of measuring the direct influence along each separate path in such a system and thus of finding the degree to which variation of a given effect is determined by each particular cause. The method depend on the combination of knowledge og the degree of correlation among the variables in a system with such knowledge as may possessed of the causal relations" (Maruyama, 1998, p. 16). 
Tabel 1 Metode Analisis Berdasarkan Tujuan Penelitian

\begin{tabular}{ll}
\hline Tujuan & Alat analisis \\
\hline $\mathrm{T}-1$ & Path Analysis \\
$\mathrm{T}-2$ & Path Analysis \\
\hline
\end{tabular}

Jadi, model path analysis digunakan untuk menganalisis pola hubungan antar variable dengan tujuan untuk mengetahui pengaruh langsung maupun tidak langsung seperangkat variabel bebas (eksogen) terhadap variable terikat (endogen).

\section{Uji Hipotesis}

Hipotesis yang diuji dalam penelitian ini adalah:

Untuk $\mathrm{T}-1$

Ho : Tidak ada hubungan yang signifikan antara Customer Relationship Management dan Marketing Public Relations terhadap Nilai Pelanggan

Ha : Ada hubungan yang signifikan antara Customer Relationship Management dan Marketing Public Relations terhadap Nilai Pelanggan

Untuk T - 2

Ho : Tidak ada hubungan yang signifikan antara Customer Relationship Management, Marketing Public Relations dan Nilai Pelanggan terhadap Loyalitas Pelanggan

Ha : Ada hubungan yang signifikan antara Customer Relationship Management, Marketing Public Relations dan Nilai Pelanggan terhadap Loyalitas Pelanggan

\section{Rancangan Implikasi Hasil Penelitian}

Rancangan implikasi hasil penelitian ini yaitu setelah semua data dan hasil analisis telah selesai dikumpulkan, maka selanjutnya dari hasil kuesioner yang dibagikan kepada Guest Grand Tropic Suites' Hotel, akan digunakan untuk menggambarkan bagaimana hubungan antara implementasi program-program Customer Relationship Management (CRM) dan Marketing Public Relations $(M P R)$ terhadap nilai pelanggan dan dampaknya terhadap loyalitas dari Guest Hotel tersebut kepada Grand Tropic Suites' Hotel.

Dari analisis diatas, apabila terdapat pengaruh dan hubungan yang kuat antara implementasi Customer Relationship Management dan Marketing Public Relations terhadap Nilai Pelanggan maka artinya program-program yang dijalankan oleh Grand Tropic Suites' Hotel sudah baik karena mampu menciptakan nilai yang baik kepada pelanggan. Jika dilihat dari nilai pelanggan yang sudah baik atau tinggi maka pelanggan atau dalam kasus ini adalah Guest dari Grand Tropic Suites' Hotel, seharusnya menjadi loyal atau setia terhadap hotel. Guest tidak sungkan untuk kembali menginap dan bahkan menggunakan fasilitas-fasilitas yang disediakan oleh hotel atau mengikuti program-program yang diselenggarakan oleh hotel. Jika program customer relationship management dan marketing public relations sudah baik, nilai pelanggan tinggi tetapi tidak menjadi pelanggan menjadi loyal terhadap hotel, berarti ada faktor lain yang menyebabkan hal ini, begitu juga sebaliknya. 


\section{HASIL DAN PEMBAHASAN}

\section{Transformasi Data Ordinal ke Interval}

Mentransformasi data ordinal menjadi data interval gunanya untuk memenuhi sebagian syarat analisis parametrik yang mana setidak-tidaknya berskala interval. Teknik transformasi yang paling sederhana dengan menggunakan MSI (Method of Successive Interval).

Tabel 2 Transformasi data variabel Customer Relationship Management

\begin{tabular}{ccc}
\hline Skala Ordinal & Berubah & Skala Interval \\
\hline Nilai Alternatif Jawaban 1 & menjadi & 1 \\
Nilai Alternatif Jawaban 2 & menjadi & 1,96 \\
Nilai Alternatif Jawaban 3 & menjadi & 2,73 \\
Nilai Alternatif Jawaban 4 & menjadi & 3,26 \\
Nilai Alternatif Jawaban 5 & menjadi & 4,90 \\
\hline
\end{tabular}

Tabel 3 Transformasi data variabel Marketing Public Relations

\begin{tabular}{ccc}
\hline Skala Ordinal & Berubah & Skala Interval \\
\hline Nilai Alternatif Jawaban 1 & menjadi & 1 \\
Nilai Alternatif Jawaban 2 & menjadi & 1,94 \\
Nilai Alternatif Jawaban 3 & menjadi & 2,82 \\
Nilai Alternatif Jawaban 4 & menjadi & 3,34 \\
Nilai Alternatif Jawaban 5 & menjadi & 4,83 \\
\hline
\end{tabular}

Tabel 4 Transformasi data variabel Nilai Pelanggan

\begin{tabular}{ccc}
\hline Skala Ordinal & Berubah & Skala Interval \\
\hline Nilai Alternatif Jawaban 1 & menjadi & 1 \\
Nilai Alternatif Jawaban 2 & menjadi & 1,97 \\
Nilai Alternatif Jawaban 3 & menjadi & 2,87 \\
Nilai Alternatif Jawaban 4 & menjadi & 3,51 \\
Nilai Alternatif Jawaban 5 & menjadi & 4,95 \\
\hline
\end{tabular}

Tabel 5 Transformasi data variabel Loyalitas Pelanggan

\begin{tabular}{ccc}
\hline Skala Ordinal & Berubah & Skala Interval \\
\hline Nilai Alternatif Jawaban 1 & menjadi & 1 \\
Nilai Alternatif Jawaban 2 & menjadi & 1,98 \\
Nilai Alternatif Jawaban 3 & menjadi & 2,96 \\
Nilai Alternatif Jawaban 4 & menjadi & 3,84 \\
Nilai Alternatif Jawaban 5 & menjadi & 4,87 \\
\hline
\end{tabular}

\section{Uji Validitas dan Reliabilitas}

Uji Validitas untuk setiap instumen dilakukan dengan terlebih dahulu dicari harga korelasi antara bagian-bagian dari alat ukur secara keseluruhan dengan cara mengkorelasikan setiap butir alat ukur dengan skor total yang merupakan jumlah tiap skor butir. Untuk menghitung validitas alat ukur digunakan rumus Pearson Product Moment. Uji validitas menggunakan tingkat kepercayaan 95\%, dimana $\mathrm{df}=\mathrm{n}-2$. Nilai $\mathrm{n}$ menggunakan data sebanyak 100 jawaban kuesioner. Jadi nilai $\mathrm{df}=98$, sehingga didapat nilai $t_{\text {tabel }}=1,66$. Selanjutnya dengan menggunakan rumus $r_{\text {tabel }}$, maka didapatkan nilai $r_{\text {tabel }}=0,1654$. 
Dasar pengambilan keputusan pada uji validitas ini adalah sebagai berikut:

Jika $\mathrm{r}_{\text {hitung }}$ positif, serta $\mathrm{r}_{\text {hitung }}>0,1654$, maka butir pertanyaan tersebut valid.

Jika $\mathrm{r}_{\text {hitung }}$ tidak positif, serta $\mathrm{r}_{\text {hitung }}<0,1654$, maka butir pertanyaan tersebut tidak valid.

Nilai $r_{\text {hasi }}$ didapat dari hasil perhitungan korelasi Pearson Product Moment antara skor tiap butir pertanyaan dengan skor total. Dasar pengambilan keputusan pada uji reliabilitas adalah sebagai berikut:

Jika Cronbach Alpha $>\mathrm{r}_{\text {tabel }}$, maka dapat dikatakan reliabel.

Jika Cronbach Alpha $<\mathrm{r}_{\text {tabel }}$, maka dapat dikatakan tidak reliabel.

Tabel 6 Hasil Uji Validitas

\begin{tabular}{lccc}
\hline \multicolumn{1}{c}{ Variabel } & $\begin{array}{c}\text { Pertanyaan yang } \\
\text { tidak valid }\end{array}$ & $\mathbf{R}_{\text {hitung }}$ & Keterangan \\
\hline Customer Relationship & Pertanyaan no. 3 & 0.074 & Tidak valid \\
Management & Pertanyaan no. 7 & 0.120 & Tidak valid \\
Marketing Public Relations & Pertanyaan no. 8 & 0.062 & Tidak valid \\
Nilai Pelanggan & - & - & - \\
Loyalitas Pelanggan & Pertanyaan no. 20 & 0.134 & Tidak valid \\
& Pertanyaan no.38 & 0.143 & Tidak valid \\
\hline
\end{tabular}

Tabel 7 Hasil Uji Reliabilitas

\begin{tabular}{ccc}
\hline Variabel & $\mathbf{R}_{\text {hitung }}$ & Keterangan \\
\hline Customer Relationship Management & 0.570 & Reliabel \\
Marketing Public Relations & 0.731 & Reliabel \\
Nilai Pelanggan & 0.804 & Reliabel \\
Loyalitas Pelanggan & 0.704 & Reliabel \\
\hline
\end{tabular}

\section{Analisis hubungan Customer Relationship Management dan Marketing Public Relations terhadap Nilai Pelanggan}

Tabel 8 Model 1: Anova

\begin{tabular}{|c|c|c|c|c|c|c|}
\hline \multicolumn{7}{|c|}{ AMONA ${ }^{b}$} \\
\hline & & $\begin{array}{l}\text { Sum of } \\
\text { Squares }\end{array}$ & $d f$ & Mean Square & $\mathrm{F}$ & Sig. \\
\hline \multirow{3}{*}{$\frac{[1.1}{1}$} & Regression & 13.314 & 2 & 6.657 & 93.364 & $.000=$ \\
\hline & Residual & 6.916 & 97 & .071 & & \\
\hline & Total & 20.230 & 99 & & & \\
\hline
\end{tabular}

Sebelum melakukan analisis jalur pada variable X1, X2 dan Y, harus diuji linieritas hubungan antara ketiga variabel tersebut. Pengujian tersebut dilakukan dengan melihat pada Tabel 8 dimana diketahui Sig $=0,000$ jika dibandingkan dengan $\alpha=0,05$, maka nilai sig lebih kecil dari $\alpha$ yang artinya Ho ditolak dan Ha diterima. Sehingga dapat ditarik kesimpulan hubungan antara variable bebas X1 dan X2 terhadap variable terikat $\mathrm{Y}$ bersifat linier dengan tingkat kepercayaan 95\%. Jadi asumsi mengenai linieritas hubungan dalam analisa jalur terpenuhi. 
Tabel 9 Model 1: Model Summary

\begin{tabular}{|l|c|c|c|c|}
\hline \begin{tabular}{l} 
Mode \\
\hline 1
\end{tabular} & $\mathrm{R}$ & R Square & $\begin{array}{c}\text { Adjusted R } \\
\text { Square }\end{array}$ & $\begin{array}{c}\text { Std. Error of } \\
\text { the Estimate }\end{array}$ \\
\hline 1 & .811 a & .658 & .651 & .26702 \\
\hline
\end{tabular}
a. Predictors: (Constant), MPR, CRM
b. Dependent Variable: NilaiPelanggan

Tabel 10 Model 1: Coefficients

Coefficients ${ }^{\mathrm{s}}$

\begin{tabular}{|c|c|c|c|c|c|c|}
\hline \multirow{2}{*}{\multicolumn{2}{|c|}{ Madel }} & \multicolumn{2}{|c|}{ Unstandardised coefficients } & \multirow{2}{*}{$\begin{array}{c}\begin{array}{c}\text { Standardized } \\
\text { Coefficients }\end{array} \\
\text { Beta }\end{array}$} & \multirow[b]{2}{*}{$\mathrm{t}$} & \multirow[b]{2}{*}{ Sig. } \\
\hline & & $\mathrm{B}$ & Std. Error & & & \\
\hline \multirow[t]{3}{*}{1} & (Constant) & 1.028 & .217 & & 4.730 & .000 \\
\hline & CRIu| & .016 & .050 & .019 & .315 & .754 \\
\hline & $\mathrm{MPR}$ & .690 & .051 & .809 & 13515 & .000 \\
\hline
\end{tabular}

a. Dependent Variable: NilaiFelanggan

\section{Rangkuman Hasil Koefisien Jalur Model 1}

Tabel 11 Rangkuman Hasil Koefisien Jalur Model 1

\begin{tabular}{cccc}
\hline Pengaruh Antar Variabel & Koefisien Jalur (beta) & Nilai Sig & Hasil Pengujian \\
\hline $\mathrm{X}_{1}$ terhadap Y & 0,019 & 0,754 & Ho diterima \\
$\mathrm{X}_{2}$ terhadap Y & 0,809 & 0,000 & Ho ditolak \\
\hline
\end{tabular}

Karena terdapat pengaruh antar variable yang tidak siginifikan (Ho diterima), maka akan dilakukan trimming terhadap model 1 dengan mengeluarkan variabel yang tidak signifikan tersebut.

Tabel 12. Model 2: ANOVA $^{\mathrm{b}}$

\begin{tabular}{|ll|r|r|r|r|r|}
\hline Model & Sum of Squares & df & Mean Square & F & \multicolumn{1}{c|}{ Sig. } \\
\hline 2 & Regression & 13.307 & 1 & 13.307 & 188.360 & $.000^{\mathrm{a}}$ \\
& Residual & 6.923 & 98 & .071 & & \\
& Total & 20.230 & 99 & & & \\
\multicolumn{2}{|l}{ a. Predictors: (Constant), MPR }
\end{tabular}

b. Dependent Variable: NilaiPelanggan

Tabel 13 Model 2: Model Summary ${ }^{\mathrm{b}}$

\begin{tabular}{|c|c|c|c|c|c|c|c|c|c|}
\hline \multirow[b]{2}{*}{ Model } & \multirow[b]{2}{*}{$\mathrm{R}$} & \multirow[b]{2}{*}{ R Square } & \multirow[b]{2}{*}{$\begin{array}{l}\text { Adjusted R } \\
\text { Square }\end{array}$} & \multirow[b]{2}{*}{$\begin{array}{l}\text { Std. Error of the } \\
\text { Estimate }\end{array}$} & \multicolumn{5}{|c|}{ Change Statistics } \\
\hline & & & & & $\begin{array}{l}\text { R Square } \\
\text { Change }\end{array}$ & F Change & df1 & df2 & Sig. F Chang \\
\hline 2 & $.811^{\mathrm{a}}$ & .658 & .654 & .26579 & .658 & 188.360 & 1 & 98 & .000 \\
\hline
\end{tabular}

a. Predictors: (Constant), MPR

b. Dependent Variable: NilaiPelanggan 
Tabel 14 Model 2: Coefficients ${ }^{\mathrm{a}}$

\begin{tabular}{|c|c|c|c|c|c|c|}
\hline \multirow{2}{*}{\multicolumn{2}{|c|}{ Model }} & \multicolumn{2}{|c|}{ Unstandardized Coefficients } & \multirow{2}{*}{$\begin{array}{c}\text { Standardized } \\
\text { Coefficients } \\
\text { Beta }\end{array}$} & \multirow[b]{2}{*}{$\mathrm{t}$} & \multirow[b]{2}{*}{ Sig. } \\
\hline & & B & Std. Error & & & \\
\hline \multirow[t]{2}{*}{2} & (Constant) & 1.071 & .166 & & 6.450 & .000 \\
\hline & MPR & .692 & .050 & .811 & 13.724 & .000 \\
\hline
\end{tabular}

Berdasarkan hasil analisis pada Tabel 14 diperoleh nilai koefisien jalur $\mathrm{X}_{2}$ terhadap $\mathrm{Y}$ sebesar $\rho \mathrm{YX}_{2}=0,811$ dengan melihat nilai Rsquare pada table Model Summary, dimana nilai $\mathrm{R}^{2}=0,658=$ $65,8 \%$. Jadi Variabel $\mathrm{X}_{2}$ mempengaruhi Variabel $\mathrm{Y}$ sebesar $65,8 \%$ dan sisanya yaitu $34,2 \%$ dipengaruhi oleh variabel-variabel lain diluar penelitian ini. Sementara itu besarnya koefisien jalur bagi variable lain diluar penelitian yang mempengaruhi nilai variable $\mathrm{Y}(\rho \mathrm{Y})=\sqrt{1-R^{2}}=$ $\sqrt{1-0,658}=0,5848$.

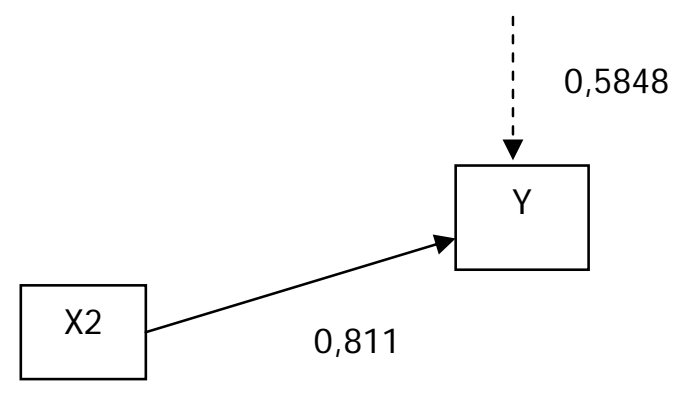

Gambar 1 Substruktur 1 beserta Koefisien Jalur

Jadi dapat diperoleh persamaan stuktural sub-struktur 1:

$\mathrm{Y}=\rho_{X 2 Y} X 2+\rho_{y} \varepsilon_{1}$

$\mathrm{Y}=0,811 \mathrm{X} 2+0,5848 \varepsilon_{1}$ dimana $\mathrm{R}^{2}=0,658$

Dari persamaan structural sub-struktur 1 dapat diartikan bahwa: (1) nilai pelanggan (Y) dipengaruhi oleh Marketing Public Relations (X2) sebesar 65,8\% dan sisanya sebesar 34,2\% dipengaruhi oleh variable-variabel lain diluar penelitian ini; dan (2) setiap peningkatan nilai Marketing Public Relations (X2) sebesar satu, maka Nilai Pelanggan (Y) juga akan naik sebesar 0,811. Begitu juga sebaliknya, setiap penurunan Marketing Public Relations (X2) sebesar satu maka Nilai Pelanggan (Y) juga akan turun sebesar 0,811 .

\section{Analisis hubungan Customer Relationship Management, Marketing Public Relations} dan Nilai Pelanggan terhadap Loyalitas Pelanggan.

Tabel 15 Model 1: Anova

ANOWA ${ }^{\text {b }}$

\begin{tabular}{|ll|r|r|r|r|r|}
\hline Model & & \multicolumn{1}{|c|}{$\begin{array}{c}\text { Sum of } \\
\text { Squares }\end{array}$} & \multicolumn{1}{c|}{ df } & Mean Square & F & Sig. \\
\hline 1 & Regression & 12.955 & 3 & 4.318 & 51.577 & $.000=$ \\
& Residual & 8.037 & 96 & .084 & & \\
& Total & 20.992 & $g 9$ & & & \\
\hline
\end{tabular}

a. Predictors: (Constant), NilaiPelanggan, CRM, MPR

b. Dependent Variable: LoyalitasPelanggan 
Sebelum melakukan analisis jalur pada variable X1, X2, Y,dan Z harus diuji linieritas hubungan antara keempat variable tersebut. Pengujian tersebut dilakukan dengan melihat pada Tabel 15 dimana diketahui Sig $=0,000$ jika dibandingkan dengan $\alpha=0,05$, maka nilai sig lebih kecil dari $\alpha$ yang artinya Ho ditolak dan Ha diterima. Sehingga dapat ditarik kesimpulan hubungan antara variable bebas X1, X2 dan Y terhadap variable terikat Z bersifat linier dengan tingkat kepercayaan 95\%. Jadi asumsi mengenai linieritas hubungan dalam analisa jalur terpenuhi.

Tabel 16 Model 1: Model Summary

\begin{tabular}{|c|c|c|c|c|}
\hline \multicolumn{5}{|c|}{ Model Summary' } \\
\hline Mode & $\mathrm{R}$ & R Square & $\begin{array}{l}\text { Adjusted R } \\
\text { Square }\end{array}$ & $\begin{array}{l}\text { Std. Error of } \\
\text { the Estimate }\end{array}$ \\
\hline 1 & $.786^{\circ}$ & .617 & .605 & .28935 \\
\hline
\end{tabular}

Tabel 17 Model 1: Coefficients

Coefficients ${ }^{3}$

\begin{tabular}{|c|c|c|c|c|c|c|}
\hline \multirow[b]{2}{*}{ Ward } & & \multicolumn{2}{|c|}{ Unstandardized coefficients } & \multirow{2}{*}{$\begin{array}{c}\text { Standardized } \\
\text { Coefficients }\end{array}$} & \multirow[b]{2}{*}{$t$} & \multirow[b]{2}{*}{ Sig. } \\
\hline & & $\mathrm{B}$ & Std. Error & & & \\
\hline \multirow[t]{4}{*}{1} & (Constant) & .366 & .261 & & 1.401 & .165 \\
\hline & CR $|w|$ & .371 & .054 & .440 & 6.912 & .000 \\
\hline & MPF & -.029 & .094 & -.033 & -.307 & .759 \\
\hline & NilaiPelanggan & .639 & .110 & .627 & 5.807 & 000 \\
\hline
\end{tabular}

a. Dependent Variable: LoyalitasPelanggan

\section{Rangkuman Hasil Koefisien Jalur Model 1}

Tabel 18 Rangkuman Hasil Koefisien Jalur Model 1

\begin{tabular}{cccc}
$\begin{array}{c}\text { Pengaruh Antar } \\
\text { Variabel }\end{array}$ & Koefisien Jalur (beta) & Nilai Sig & Hasil Pengujian \\
\hline $\mathrm{X}_{1}$ terhadap Z & 0.440 & 0.000 & Ho ditolak \\
$\mathrm{X}_{2}$ terhadap Z & -0.033 & 0.759 & Ho diterima \\
Y terhadap Z & 0.627 & 0.000 & Ho ditolak \\
\hline
\end{tabular}

Karena terdapat pengaruh antar variable yang tidak siginifikan (Ho diterima), maka akan dilakukan trimming terhadap model 1 dengan mengeluarkan variabel yang tidak signifikan tersebut.

Tabel 19. Model 2: Model Summary ${ }^{\mathrm{b}}$

\begin{tabular}{|c|c|c|c|c|c|c|c|c|c|}
\hline \multirow[b]{2}{*}{ Model } & \multirow[b]{2}{*}{$\mathrm{R}$} & \multirow[b]{2}{*}{ R Square } & \multirow[b]{2}{*}{$\begin{array}{c}\text { Adjusted R } \\
\text { Square }\end{array}$} & \multirow[b]{2}{*}{$\begin{array}{c}\text { Std. Error of the } \\
\text { Estimate }\end{array}$} & \multicolumn{5}{|c|}{ Change Statistics } \\
\hline & & & & & $\begin{array}{l}\text { R Square } \\
\text { Change }\end{array}$ & F Change & df1 & $\mathrm{df} 2$ & Sig. F Change \\
\hline 2 & $.785^{\mathrm{a}}$ & .617 & 609 & .28800 & .617 & 78.047 & 2 & 97 & .000 \\
\hline
\end{tabular}

a. Predictors: (Constant), CRM, NilaiPelanggan

b. Dependent Variable: LoyalitasPelanggan 
Tabel 20. Model 2: ANOVA $^{\mathrm{b}}$

\begin{tabular}{|c|c|c|c|c|c|c|}
\hline \multicolumn{2}{|c|}{ Model } & Sum of Squares & $\mathrm{df}$ & Mean Square & $\mathrm{F}$ & Sig. \\
\hline \multirow[t]{3}{*}{2} & Regression & 12.947 & 2 & 6.473 & 78.047 & $.000^{\mathrm{a}}$ \\
\hline & Residual & 8.045 & 97 & .083 & & \\
\hline & Total & 20.992 & 99 & & & \\
\hline
\end{tabular}

Tabel 21 Model 2: Coefficients ${ }^{\mathrm{a}}$

\begin{tabular}{|c|c|c|c|c|c|c|}
\hline \multirow{2}{*}{\multicolumn{2}{|c|}{ Model }} & \multicolumn{2}{|c|}{ Unstandardized Coefficients } & \multirow{2}{*}{$\begin{array}{c}\text { Standardized } \\
\text { Coefficients }\end{array}$} & \multirow[b]{2}{*}{$\mathrm{t}$} & \multirow[b]{2}{*}{ Sig. } \\
\hline & & $\mathrm{B}$ & Std. Error & & & \\
\hline \multirow[t]{3}{*}{2} & (Constant) & .365 & .260 & & 1.405 & .163 \\
\hline & NilaiPelanggan & .612 & .064 & .600 & 9.483 & .000 \\
\hline & CRM & .370 & .053 & .439 & 6.938 & .000 \\
\hline
\end{tabular}

a. Dependent Variable: LoyalitasPelanggan

Besarnya pengaruh variable $\mathrm{X}_{1}$ dan $\mathrm{Y}$ terhadap $\mathrm{Z}$ secara simultan dapat diketahui dengan melihat nilai Rsquare pada table Model Summary, dimana nilai $\mathrm{R}^{2}=0,617=61,7 \%$. Jadi Variabel $\mathrm{X}_{1}$ dan Y mempengaruhi Variabel Z sebesar $61,7 \%$ dan sisanya yaitu 38,3\% dipengaruhi oleh variabelvariabel lain diluar penelitian ini. Sementara itu besarnya koefisien jalur bagi variable lain diluar penelitian yang mempengaruhi nilai variabel $Z(\rho Z)=\sqrt{1-E^{2}}=\sqrt{1-0,617}=0,6189$.

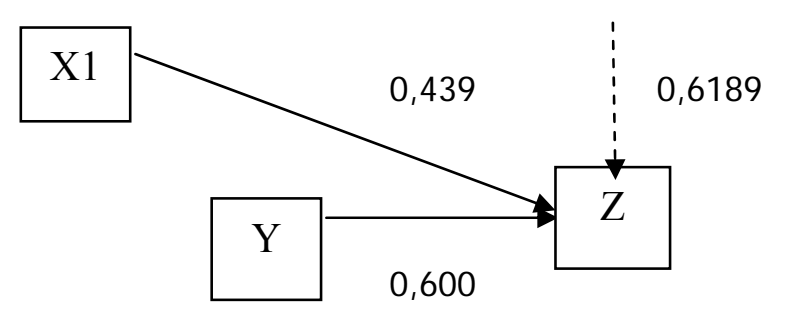

Gambar 2 Substruktur 2 beserta Koefisien Jalur

Jadi dapat diperoleh persamaan stuktural sub-struktur 2:

$\mathrm{Z}=\rho_{\mathrm{zx} 1} \mathrm{X} 1+\rho_{\mathrm{zy}} \mathrm{Y}+\rho_{\mathrm{Z}} \varepsilon_{2}$

$\mathrm{Z}=0,439 \mathrm{X} 1+0,600 \mathrm{Y}+0,6189 \varepsilon_{2}$ dimana $\mathrm{R}^{2}=0,617$

Dari persamaan struktural sub-struktur 2 dapat diartikan bahwa: (1) Loyalitas Pelanggan (Z) dipengaruhi oleh Customer Relationship Management $\left(\mathrm{X}_{1}\right)$, dan Nilai Pelanggan (Y) secara simultan sebesar $61,7 \%$ dan sisanya sebesar 38,3\% dipengaruhi oleh variable-variabel lain diluar penelitian ini; (2) setiap peningkatan nilai Customer Relationship Management $\left(\mathrm{X}_{1}\right)$ sebesar satu, maka Loyalitas Pelanggan (Z) juga akan naik sebesar 0,439. Begitu juga sebaliknya, setiap penurunan Customer Relationship Management $\left(\mathrm{X}_{1}\right)$ sebesar satu, maka Loyalitas Pelanggan $(\mathrm{Z})$ juga akan turun sebesar 0,439; dan (3) setiap peningkatan Nilai Pelanggan (Y) sebesar satu, maka Loyalitas Pelanggan (Z) juga akan naik sebesar 0,600. Begitu juga sebaliknya, setiap penurunan Nilai Pelanggan (Y) sebesar satu maka Loyalitas Pelanggan (Z) juga akan turun sebesar 0,600. 
Jadi keseluruhan pengaruh kausal variable Customer Relationship Management (X1) dan Marketing Public Relations (X2) terhadap Nilai Pelanggan (Y) dan dampaknya terhadap Loyalitas Pelanggan $(Z)$ dapat digambarkan dalam model struktur lengkap sebagai berikut:

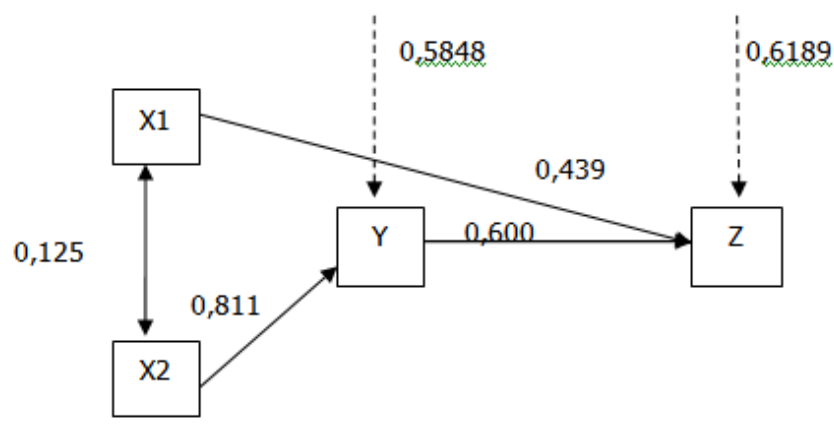

Gambar 3 Struktur Lengkap beserta Koefisien Jalur

\section{PENUTUP}

Customer Relationship Management dan Marketing Public Relations secara bersama-sama memberikan pengaruh terhadap Nilai Pelanggan sebesar 65,8\%. Marketing Public Relations memberikan pengaruh yang sangat kuat dan searah terhadap Nilai Pelanggan, yaitu setiap kenaikan satu satuan Marketing Public Relations maka Nilai Pelanggan akan naik sebesar 0,811 dan setiap penurunan satu satuan dari Marketing Public Relations maka Nilai Pelanggan juga akan turun sebesar 0,811. Customer Relationship Management, Marketing Public Relations dan Nilai Pelanggan secara bersama-sama memberikan pengaruh terhadap Loyalitas Pelanggan sebesar 61,7\%. Di mana Nilai Pelanggan memberikan pengaruh yang kuat dan searah terhadap Loyalitas Pelanggan, yaitu setiap kenaikan satu satuan dari nilai pelanggan, maka Loyalitas Pelanggan juga akan naik sebesar 0,600 dan setiap penurunan satu satuan dari nilai pelanggan maka Loyalitas Pelanggan juga akan turun sebesar 0,600. Customer Relationship Management Management memberikan pengaruh yang cukup kuat dan searah terhadap Loyalitas Pelanggan, yaitu setiap kenaikan satu satuan dari Customer Relationship Management maka Loyalitas Pelanggan juga akan naik sebesar 0,439 dan setiap penurunan satu satuan dari Customer Relationship Management maka Loyalitas Pelanggan juga akan turun sebesar 0,439.

\section{Saran}

Dengan memperhatikan hasil analisa dan pembahasan diatas, maka saran-saran yang dapat diberikan kepada Grand Tropic Suites' Hotel adalah: sebaiknya program-program Customer Relationship Management lebih ditingkatkan lagi karena memberikan hasil yang cukup efektif terhadap pembentukan Loyalitas Pelanggan. Sebaiknya program-program Marketing Public Relations ditinjau dan diperbaiki lagi karena kurang memberikan pengaruh terhadap pembentukan Loyalitas Pelanggan. Intensitas aktifitas dari Marketing Public Relations lebih ditingkatkan lagi, misalnya melalui artikel-artikel, majalah hotel, media cetak dan elektronik. Rancanglah suatu program baru untuk meningkatkan Nilai Pelanggan karena terlihat bahwa hubungan antara Nilai Pelanggan dengan Loyalitas Pelanggan kuat, karena dengan menciptakan Nilai pelanggan yang superior dapat dapat meningkatkan Loyalitas. Program-program $C R M$ dan $M P R$ yang kurang efektif seperti Continuity marketing dan Press Release ditingkatkan lagi. Penanganan keluhan lebih diperbaiki lagi karena terbukti bahwa keluhan Guest Hotel dirasa kurang ditanggapi dan ditangani dengan baik. Analisa dan kembangkan faktor-faktor lain yang dapat mempengaruhi Nilai Pelanggan dan Loyalitas Pelanggan 
karena Customer Relationship Management dan Marketing Public Relations mempengaruhi Nilai Pelanggan sebesar $65,8 \%$, masih terdapat $34,2 \%$ factor lain yang mempengaruhi Nilai Pelanggan. Dan Customer Relationship Management dan Public Relations serta Nilai Pelanggan mempengaruhi Loyalitas Pelanggan sebesar $61,7 \%$ masih terdapat $38,3 \%$ faktor-faktor lain yang mempengaruhi Loyalitas Pelanggan.

\section{DAFTAR PUSTAKA}

Griffin, J. (2002). Customer loyalty: How to earn it, how to keep it. Kentucky, USA: McGraw-Hill.

Kotler, P., Bowen, J., \& Makens, J. (2005). Marketing for hospitality and tourism. New Jersey: Prentice Hall.

Kotler, P. (2007). Marketing management. New Jersey: Prentice Hall.

Riduwan, \& Kuncoro, E. A. (2007). Cara menggunakan dan memaknai analisis jalur (path analysis). Bandung: Alfabeta.

Wahyuningsih. (2004). Customer value: Concept, operationalization, and outcome. Usahawan. Agustus, No.8 TH XXXIII. 